Јелена Филиповић

Универзитет у Београду

Филолошки факултет
UDC 81'243(497.11)

DOI https://doi.org/10.18485/fid.2018.8.ch1

\title{
ЈЕЗИЧКА ПОЛИТИКА И ПЛАНИРАЫЕ И ЈЕЗИЧКО ПРЕДВОДНИШТВО: ОБРАЗОВАЊЕ ЗА 21. ВЕК ${ }^{1}$
}

\begin{abstract}
Сажетак
У раду се представља критички осврт на концепт језичке политике и планирања и језичке образовне политике кроз анализу кључних принципа њиховог функционисања, језичког менаџмента и језичког предводништва. Студија случаја у којој се представљају искуства групе студенткиња које су на мастер студијама Филолошког факултета Универзитета у Београду стекле знања о језичкој политици и планирању кроз призму критичке педагогије и критичке лингвистичке анализе потврђује идеју да језичка политика у 21. веку не може да се спроводи искључиво “одозго-на-доле”, већ да у обзир мора да узме и променљиве категорије индивидуалних и колективних комуникативних и афективних потреба заинтересованих говорних заједница.
\end{abstract}

Кључне речи: језичка политика и планирање, језичка образовна политика, језички менаџмент, језичко предводништво, образовни систем Србије.

\section{1. Критички увид у језичку политику и планирање}

Језичка политика и планирање у кључу који овде користим представља интедисциплинарну научну област која користи теоријске принципе и методолошке поступке читавог низа хуманистичких и друштвених дисциплина, попут социолингвистике, примењене лингвистике, социологије, друштвене теорије, антропологије, критичке анализе дискурса, критичке педагогије и других. Она се тако уклапа у контекст критичке лингвистичке анализе која покушава да језик сагледа као део

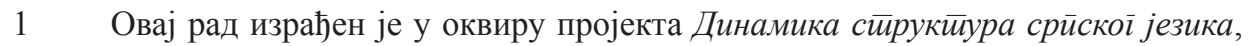
178014 , који финансира Министарство просвете, науке и технолошког развоја Републике Србије. 
комплексног система друштвеног бивствовања и интеракције у приватном, јавном, образовном и професионалном домену језичке употребе.

Језичка политика и планирање као друштвена делатност вероватно је стара колико и организација људских друштава. Потреба за комуникацијом унутар уређених друштвених устројстава, ма у ком облику се она реализовала, увек је подразумевала доношење низа одлука о томе шта је прихватљиво језичко понашање, односно понашање које успева да пренесе жељену поруку и значење које ће бити препознато и валоризовано од осталих учесника у комуникативном чину. То подразумева и примену стратегија које подразумевају позитивно или негативно “лице” (енгл. face-saving или face-threatening strategies; за детаљније информације, в. Гофман, 1967; Браун \& Левинсон, 1987, Фрејжер, 1990, Илен, 2001 и други), то јест, одређивање и употребу језичких структура и лексема које регулишу квалитет међуљудских односа унутар једне говорне заједнице и дефинишу односе друштвене моћи на скали друштвеног утицаја појединаца и група у датој говорној заједници.

Реч “политика" у српској терминолошкој синтагми устаљеној у стручној и академској литератури има већи број значења од речи policy у енглеском језику из кога је преузета из разлога што се од 60их година 20. века (од када језичка политика и планирање има статус научне дисциплине) наовамо на том језику формулишу и аргументују научне оријентације и постулати који је сврставају у ред најдинамичнијих области истраживања у сфери односа језика и друштва (Филиповић, 2015, Филиповић, 2009, Рисенто, 2000; 2006). Српска реч “политика" подразумева две речи и два значења која стоје у контрастном односу у енглеском језику (politics и policy), и из перспективе критичке језичке политике ми се стога наш одабир лексеме чини релевантнијим и адекватнијим од онога у језику изворнику. Наиме, енглеска реч politics се директно повезује са институционализацијом друштвене моћи и подразумева друштвено-политичку активност која се заснива на праву приступа инструментима одлучивања, хијерархији, легитимитету, као и постојању бирократског и технократског система (Шнајдер \& Инграм, 1993). Политика (енгл. policy) представља једну релативно схваћену когнитивно-антрополошку шему која укључује друштвена 
знања која се преносе грађанству и утичу на њихове ставове, идеологије и свест о учешћу у процесу одлучивања: “ Политика (policy) дефинише проблеме које треба решити и циљеве које треба достићи и идентификује особе чије је понашање у складу са реализацијом жељених намера ${ }^{20}$ (Шнајдер \& Инграм, 1993: 355).

\section{2. Менаџмент и предводништво/лидерство ${ }^{3}$ у језичкој политици и планирању}

Традиционално тумачење језичке политике и планирања се усмерава на хијерархизоване принципе деловања појединаца или институција са позиција друштвене моћи, односно онога што се назива језичка политика “одозго-на-доле”, те се лако може повезати са термином политика у горе наведеном првом значењу ове речи у енглеском језику. Језичка политика у том смислу, у коме се углавном и сагледава, посебно ван научног контекста, јесте процес кроз који се једној језичкој и/или политичкој заједници језичке идеологије и механизми њихове институционализације формирају, перпетуирају и/или мењају кроз утицај институција и угледних појединаца који представљају њихове експоненте, односно носиоце симболичне моћи у свим јавним доменима језичке употребе (администрација, образовање, медији, јавни дискурс, итд.). Међутим, савремена критичка (социо)лингвистичка теорија сагледава и анализира и концепт је-

2 "Policy sets forth problems to be solved or goals to be achieved and identifies the people whose behavior is linked to the achievement of desired ends." (Н.Б. сви преводи у тексту су дело ауторке рада)

3 С обзиром на чињеницу да у српском језику не постоји одговарајући преводни еквивалент за енглески термин management,већ се стога одомаћио интернационализам менаџмент, у раду користим дублет предводништво и лидерство (енгл. leadership) како бих указала на семантичку везу између два појма и њихове терминолошке рефлексе у српском језику (иако реч предводништво заправо сасвим одговара енглеском термину leadership), управо како бих и на примеру терминолошке језичке политике показала како ни процес фискирања термина није тренутан и како се мора исфилтрирати кроз време и употребу. Енглеска реч management се често на српски погрешно преводи речју управљање, за коју је енглески еквивалент термин control. 
зичке политике “одоздо-на-горе” која је такође вероватно подједнако стара и колико и она "одозго-на-доле", али која до недавно није представљала тему интересовања академске јавности. У том смислу, дефинишем две основне парадигме језичке политике: језичка политика “одозго-на-доле”, која се увек повезује да институцијама система и позицијама моћи, односно увек је у директној спрези са језичким менаџментом (Сполски, 2009), и језичка политика “одоздо-на-горе”, коју дефинишем кроз концепт језичког предводништва или лидерства (Филиповић, 2015, Филиповић, 2016, Филиповић, 2017).

Језичка политика која се првенствено спроводи кроз менаџмент језика подразумева присуство особа или институција којима се даје формално право, легитимитет, па тиме и ауторитет (заслужен или не) да доносе одлуке које се потом спроводе у свим областима друштвеног живота. Менаџмент у пракси језичке политике и планирања такође значи да ауторизовани ентитети (особе или институције) имају право и моћ да моделирају језичка уверења говорне заједнице, односно да модификују њихове говорне праксе, бар у јавним доменима језичке употребе. Другим речима, у оквиру овакве парадигме језичке политике се у име говорних заједница доносе одлуке о томе како треба да користимо језик, који језички варијетет је прихватљив а који не, односно који језици имају права да се позиционирају као релевантни у домену образовања и јавног дискурса (у најширем смислу). Ово као и већина других активности у области језичке политике, свакако, нису одлуке које су у било каквој вези са суштином и структуром језичких система, већ искључиво базиране на ставовима појединаца и колективним идеологијама које указују на опште вредносне категорије друштвених и политичких заједница у којима се дефинишу и спроводе ${ }^{4}$. Овакав модел представља окосницу европске језичке политике од периода формирања модерне науке у доба Просветитељства, и базиран је на језичком прескриптивизму и хијерархијском позиционирању онога што се дефинише као “чист”, “правилан”, “савршен” језик у односу на све остале варијетете присутне на једном географком и политичком простору (Филиповић, 2015; Бауман \& Бригс,

4 в. Филиповић 2015, за детаљну анализу концепта стандарднојезичке културе који се најчешће повезује са оваквом врстом језичке политике. 
2003; Хераертс, 2003). За аргументацију која следи, посебно је важно овакво виђење језика контекстуализовати у један шири епистемолошки оквир, повезати га са поимањем науке уопште: "Пошто је знање нераскидиво повезано са вредновањем, ниједан политички систем не прихвата самопрокламовану тезу (...) о вредносној неутралности науке и образовања. (...) Врло је индикативно да данас постоји темељна сагласност сукобљених политичких оријентација, заинтересованих за доминацију на универзитету и обликовање његовог профила, о доме да је високо школсивво иривилеіовано месйо рейрояукиије кулииурних вреgносии" (Жуњић, 2009: 322, курзив мој). Управо нас ова одредница повезује да преводом термина policy као политика у контексту језичке политике и планирања. Ново доба, или модерност, доноси, између осталог, и идеју о објективној науци коју треба преточити у вредносне системе модерних друштава. У том смислу, ЈПП постаје и инструмент којим се, као што је већ наведено, дефинишу циљеви и идентификују ентитети које те циљеве могу да спроведу. А то нас уједно приближава разумевању суштинске идеје језичке политике “одоздо-на-горе”, односно језичком предводништву/лидерству.

Језичка политика “одоздо-на-горе” користи сличне механизме као она “одозго-на-доле”, али при томе не примењује утемељене друштвене хијерархије и присуство менаџера који своје одлуке заснивају на ауторитету институција, већ на хетерархијском ${ }^{5}$ устројству које условљава и конструише партнерски однос, оснаживање појединаца, умрежавање, тимски рад, све то у специфичном контексту који изнедрава нова значења (Витли, 2004, Филиповић, 2015). Језик је, као што учимо од првог часа уводног курса у општу лингвистику, жива материја, која се мења кроз време и простор (дијахронијски и дијатопијски), али и кроз контексте и делатне заједнице на синхронијској равни. Језик није само средство за преношење денотативних значења, већ и сложен систем који свима нама представља једну од окосница у процесу индивидуализације и формирања личних и колективних иден-

5 Хетерархија се односи на само-организацију, изнедрено понашање и латерално дистрибуирану одговорност (Старк, 2001, цит. у Филиповић, 2015: 38). Изнедравање овде дефинишем као “појаву нових, кохерентних структура и образаца у процесу само-организације” (Голдстин, 1999, цит. у Филиповић, 2015: 35). 
титета. У том смислу, језичка политика, како је ја сагледавам, треба да прати и задовољава комуникативне и афективне потребе различитих делатних заједница, односно, да буде флексибилна и спремна да препозна и прихвати друштвене промене које своје огледало налазе и у језику. Предводништво у језичкој политици значи да свако од нас има права да преузме улогу зачетника језичке иновације, која ће, (баш као што то наводи и универзална теорија језичке промене, в., нпр.,Томасон \& Кауфман, 1988, Филиповић, 1999, између осталих) бити регистрована као део језичког система тек када буде прихваћена на нивоу “критичне масе", односно довољног броја говорника који ће је “профилтрирати" кроз велики број комуникативних интеракција. Тако изнедрена језичка иновација (форма, структура, комуникативна пракса, и др.) може и треба да своје место нађе и у окриљу језичке политике која ће је препознати и укључити у процес континуираног корпусног планирања. Тако се језичка политика “одоздо-на-горе” повезује и са теоријом учтивости, поменутом у првом пасусу овог рада, и са комуникацијом која се руководи принципима кооперације и сарадње, а не такмичења или сукоба (Традгил, 1983). Другим речима, одабири и примена иновативних језичких форми и структура у смисленим комуникативним акцијама на индивидуалном и на плану заинтересованих делатних заједница једна је од кључних активности језичке политике “одогдо-на-горе”. Али таква активност подразумева поштовање различитости ставова и уважавање супротних мишљења, никако наметање нових модела као једино прихватљивих или инсистирање на већ етаблираној искључивој “правилности" утемељених стандардних форми и структура.

\section{3. Језичка образовна политика и предводништво/лидерство}

У контексту језичке образовне политике, која се бави присуством и заступљеношћу језика̂ у (пре свега формалним) образовним системима, изнедрена иновација може се такође односити на присуство новог језичког варијетета или новог језика у образовању, као и на увођење нових наставних метода и техника, односно, на ревидирање наставних програма за које су задужене институције система (у нашој земљи, то су Министарство просвете, науке и технолошког развоја, 
Завод за унапређење образовања и васпитања, Завод за вредновање образовања и васпитања, Филолошки факултет Универзитета у Београду, филолошке катедре филозофских факултета других српских универзитета, САНУ и Матица Српска).

Језичко предводништво такође укључује и перспективу критичке педагогије (Хокинс \& Нортон, 2009) која образовање тумачи као простор у коме се формирају делатне заједнице професорки и професора са једне стране, и ученика и ученица са друге стране. Учионица у критичко педагошком приступу дефинише се као место које служи учењу у заједници и конструкцији знања кроз различите образовне парадигме у чијој основи лежи тимски рад који поштује и негује индивидуалне разлике, креативна потрага за информацијама и њихова систематизација и структурирање у смислене крос-курикуларно дефинисане оквире постигнућа.

На овом месту се читалац или читатељка са правом могу запитати у каквој вези стоје горе наведени концепти критичке педагогије, језичке образовне политике и предводништва. У наредним редовима покушаћу да ту везу појасним.

Са тим циљем, уводим и појам образовног предводништва/лидерства, које се односи на професорке и професоре који компетентно примењују наставне методе и технике како би критички анализирали постојеће језичке образовне политике и оснажили своје ученике и ученице/студенткиње и студенте да узму активног учешћа у њиховом промишљању, осмишљавању нових приступа и формулисању нових локализованих језичких образовних политика који стоје у хармоничној вези са ширим, националним или регионалним образовним политикама, а задовољавају индивидуалне и колективне потребе одређених делатних заједница (састављених од родитеља, деце, административне и образовне власти, локалних креатора политике запошљавања и сл.). Дакле, језичко предводништво овде пре свега сагледавам из угла образовања будућег наставног кадра у области образовања језика̂ (матерњег, страног, мањинског језика) у формалном образовању кроз које студенти и студенткиње на универзитетском нивоу треба да буду оснажени и оспособљени за заузимање критичког става према језичким образовним политикама и према институцијама које их конструишу и имплементирају менаџерски, “одозго-на-доле”. Њихово 
академско образовање у функцији припреме за рад у учионици треба да им, између осталог, обезбеди способност да предузму проактивну акцију у формирању и имплементацији језичких образовних политика у сфери њиховог професионалног деловања и интересовања. Као и језичке политике уопште, језичке образовне политике такође увек стоје у интеракцији са идеологијама које их условљавају и формулишу (Толефсон, 2002, цит. у Филиповић, 2015: 100), те је стога неопходно будућим професоркама и професорима различитих језика обезбедити довољно теоријских знања и практичних вештина које ће им помоћи да разумеју макро и микро елементе функционисања језичких образовних политика које треба да у учионици имплементирају (општи друштвено-политички контекст на локалном, националном, регионалном и интернационалном плану; разлоге за одабир датих комуникацијских кодова, жанрова и регистара, аргументе за афирмацију и оснаживање, односно, одбијање одређених језичких и других идентитета, као и принципе селекције наставних материјала, садржаја и метода и техника које национални курикулум намеће).

Овиме се на будуће наставнице и наставнике такође преноси и део одговорности за њихово функционисање унутар формалних образовних система. Предуслов за ово делегирање одговорности свакако представља отварање приступа “кључним знањима, вештинама и вредностима" ${ }^{6 "}$ (Кели и др., 2004) која се у критичкој педагогији укључују у предуслове за функционалну и успешну наставу и учење.

\section{4. Критичко универзитетско образовање наставног кадра као предуслов за предводништво у језичкој образовној полити- ци}

Када је настава језика̂ у питању, критичко образовање будућег наставног кадра је од кључног значаја, и то образовање дефинисано као контекстуализована пракса кроз учествовање, не кроз учење, (Лејв 1988) док учествовање значи еволуирајуће, (изнедрено) члан-

6 "common core of knowledge, skills and competences" 
ство у хетерархијским делатним заједницама (Филиповић \& Јовановић, 2016). Циљ оваквог академског приступа јесте оснаживање младих људи, развој способности за самокритику и критику, али пре свега унапређења самопоуздања свих укључених у овај процес, путем увођења нових тема, нових приступа и углова гледања кроз иновативне дискурзивне праксе изван крутих клишеа академске културе и академског дискурса. Један од основних разлога за овакав став је сасвим очигледан: наставнице и наставници (не само језика већ и осталих предмета) играју значајну улогу у формирању идентитета деце са којом раде. Стога они имају и потенцијалну кључну улогу у деконструкцији друштвене неравноправности и маргинализације осетљивих етнолингвистичких и других група. Они су ти који у значајној мери формирају дечије идеологије, вредносне системе и перспективе у односу на свет који их окружује. А велики део тих вредносних система конструише се и перпетуира кроз језик и у језику. Критичка педагогија у спрези за језичким образовним политикама, дакле, “образовање сагледава у функцији континуиране борбе око тога шта ће постати легитимизирано знање и култура (Дардер, 1995: 77), за разлику о традиционалног позитивистичког, објективистичког приступа који наводи да је образовање неутрално и аполитично. Дакле, све горе наведено треба да буде део образовног процеса кроз који будући наставни кадар пролази пре уласка у образовни систем.

Стога, академско образовање будућих наставница и наставника језика̂ сагледавам из перспективе критичке педагогије кроз призму заинтересованих професионалних делатних заједница које су оснажене и опремљене адекватним теоријским и практичним знањима и умењима, способне за критичку анализу језика и језичких политика, захваљујући чему могу постати агенси промене у образовању у области језика на различитим нивоима (образовним, географским, политичким, итд.). Студија случаја коју представљам у наредном одељку нуди илустрацију образовног модела који отвара простор за преиспитивање постојећих и формирање нових образовних и

7 “(...) schooling functions as a terrain of ongoing struggle over what will be accepted as legitimate knowledge and culture". 
општих идеолошких поставки у социо-образовном контексту у коме се спроводи формално образовање, са циљем да изнађу алтернативна, прихватљивија и сврсисходнија решења проблема са којима се наставнице и наставници суочавају.

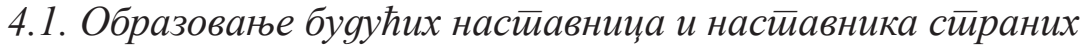 језика у Србији и на Филолошком факулиетйу Универзитетей у Беоїраgу}

Закон о основама система образовања и васпитања (Службени гласник Републике Србије бр. 72/2009, 52/2011 и 55/2013) одређује све аспекте образовног система на основношколском и средњошколском нивоу у Србији. Институције високог образовања у обавези су да своје наставне програме делимично прилагођавају захтевима које пред будуће наставнике и наставнице поставља овај Закон: свака особа запослена у наставном процесу у формалном образовном систему Србије мора да има диплому мастера и 36 академских психолошко-педагошко-методичких кредита (бодова); од тога 30 кредита стечених кроз похађање наставе на високошколској установи и 6 кредита наставне праксе у некој од установа основношколског или средњошколског образовања. Овај услов, наравно, морају да задовоље и будући наставници и наставнице страних језика, и он се остварује кроз наставу на основним и мастер студијама Филолошког факултета Универзитета у Београду (као и кроз наставне програме филолошких катедара других српских универзитета).

Наставни програм који се томе реализује на Филолошком факултету Универзитета у Београду стога садржи елементе језичких образовних политика, критичке педагогије, социолингвистике образовања и критичке језичке анализе (поред методичких и психолошко-педагошких предмета који се традиционално нуде у контексту сличних образовних профила). Овако постављен курикулум нуди интердисциплинарни и трансдисцплинарни приступ образовању наставног кадра, који, поред компетенција у циљном језику, културама и цивилизацијама говорника који га користе као Л1, предвиђа и увођење и развијање интеркултурне, педагошке, прагматичке и критичке лингвистичке компетенције уз упознавање са социо-политичким, кутурним и исто- 
ријским контекстом у коме се образовни процес у који треба да уђу по завршетку студија одвија. У методологију рада уводе се концепти савремених квалитативних истраживања, који укључују акционо истраживање са учешћем које их оспособљава за самостално, активно и критичко промишљање сопственог деловања у учионици.

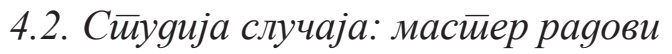

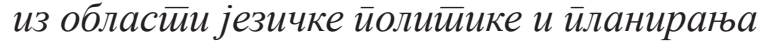 на Кайеgри за иберијске сйудије}

Студија случаја која се овде представља полази од анализе двадесет девет мастер радова студенткиња и студената који су на мастер студијама похађали такозвани “ппм модул" (психолошко-педагошко-методичке предмете) и који су за истраживање спроведено при изради мастер радова одабрали област језичке политике и планирања или језичке образовне политике. Сви радови су успешно одбрањени током 2009/10, 2010/11, 2011/12 и 2012/13 школске године на Катедри за иберијске студије Филолошког факултета Универзитета у Београду, и сви представљају резултате самосталних емпиријских истраживања спроведених методологијом студија случаја анализе различитих аспеката језичких образовних политика у Србији, Шпанији и другим земљама хиспанског говорног подручја.

Критичко читање ових радова без изузетка указује на висок ниво способности за критичко мишљење њихових ауторки и аутора, који се лако и успешно сналазе у идентификацији проблематичних места и предлагању могућих решења унутар образовних система које анализирају. С обзиром на чињеницу да се мастер рад на овој катедри сматра “круном" академског образовања за већину студенткиња и студената, одабир теме за мастер рад је искључива обавеза самих кандидаткиња и кандидата. Уз препознавање важности и незаобилазности подршке менторки и ментора у овом процесу, дефинисање теме, претраживање литературе, постављање хипотеза и одабир методолошких поступака третирају се као саставни део академског сазревања кроз који се стиче способност за самостални истраживачки рад. Дакле, сама чињеница да је 29 мастер радова написано и одбрањено 
на тему језичких и језичких образовних политика у периоду од само четири школске године говори и о томе да су концепти и садржаји уведени на релевантним предметима на мастер студијама (Сйецијалне иеме из иримењене линівистиике, Сиецијалне иееме из социолинївистии-

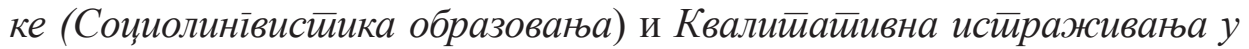
линївистиии) пронашли плодно тле и омогућили ширење академских видика и развој интелектуалне радозналости одређеног броја студенткиња и студената који су их увели у даљи увид у теме у вези са језичким образовним политикама и језичким политикама уопште.

У циљу провере идеје о значају развоја предводништва кроз критичку педагогију и критичку језичку и социолингвистичку анализу у процесу високошколског образовања будућег наставног кадра, спроведени су полу-структурирани интервјуи са 8 студенткиња (узраста од 25 до 29 година), које чине део веће групе од горе наведених двадесет и деветоро, а које су по дипломирању и стицању мастер дипломе радно место пронашле у школама широм Србије или у образовним институцијама државног система. Свих осам учесница у истраживању изјавило је да је мастер програм за образовање наставног кадра у области страних језика представљао пивоталну тачку у њиховом процесу одлучивања у вези са темом мастер рада и будућом професионалном оријентацијом.

Исто тако, све учеснице у истраживању сматрају да њихове одлуке стоје у директној корелацији са академским знањима која су стекле током мастер студија, а која су им омогућила да критички тумаче концепте језичких и језичких образовних политика и њихов утицај на друштво у целини: “Чини се да је језичка политика преломна тачка у процесу доношења великог броја одлука од друштвеног и политичког значаја у савременом свету”, навела је једна од учесница. "Емпиријско истраживање које сам спровела током израде мастер рада натерало ме је да преиспитам сопствено схватање језичке политике и планирања. Такође сам имала прилике да теоријска и практична знања из ове области применим у својој професионалној сфери по завршетку мастер студија", закључила је друга учесница истраживања.

Учесница која се у свом мастер раду бавила језичким политикама у земљама насталим на територији СФРЈ истакла је да су предмети које је похађала на мастеру и истраживање које је спровела током из- 
раде завршног рада инспирисали да поново промисли концепт стандардног језика, однос језика и националног идентитета и помогли јој да разуме манипулативну улогу језичке политике “одозго-на-доле" на Балкану. Закључила је да је ово академско искуство охрабрило и учинило спремном да јавно заступа своје ставове и да их поткрепи научно заснованим аргументима.

Друга учесница је пак изнела став да јој је овај образовни модел помогао да схвати интеракцију екстралингвистичких и лингвистичких фактора који играју улогу у формирању јавног мњења, друшвених хијерархија и хегемонијску (зло)употребу језика у различитим културним и социо-политичким контекстима.

Једна од учесница која се професионално бави менаџментом људским ресурсима установила је да јој је мастер рад помогао да разуме како елементи језичке политике и планирања превазилазе академски дефинисане границе дисциплина статусне, корпусне и образовне језичке политике, те да језичка политика и планирање игра веома значајну улогу у формирању свих дискурзивних пракси у јавним и професионалним комуникативним доменима.

Једна од учесница у овој студији случаја се у свом мастер раду бавила питањем билингвизма у етнолингвистичким мањинским заједницама у Србији кроз истраживање утицаја билингвалног образовања на когнитивни и друштвени развој деце, те на формирање њиховог идентитета. Она се одлучила за емпатијски етнографски приступ и у раду изнела резултате које је потом успела да представи и образовним властима на локалном и окружном нивоу, као и академској публици на једној националној лингвистичкој конференцији, у циљу афирмације адитивног билингвизма у етнолингвистичким мањинским заједницама у нашој земљи.

Пет учесница у овом истраживању које данас раде као професорке страних језика су током интервјуа изнеле чињеницу да су у својој наставној пракси до сада имале прилику да своје знање и искуство у области језичких образовних политика поделе са колегиницама и колегама у својим професионалним делатним заједницама и да су повратне реакције увек биле охрабрујуће, то јест, да су школске власти и школски одбори позитивно реаговали на њихове предлоге у вези са понудом већег броја страних језика у школама у којима предају. Исто 
тако, потврдиле су да су имале веома добра искуства са применом иноватнивних наставних метода и техника којим су успеле да образовни процес пренесу из традиционалног оквира учионице у локални друштвени и културни контекст у складу са интересовањима деце са којом раде. Закључујем да су ових пет учесницасебе већ формирале као предводнице у својим делатним заједницама са јасном идејом да својом акцијом стварају услове за конструкцију новог простора за учење и делање који задовољава потребе деце, родитеља, локалних заједница и образовних власти у циљу афирмације плурикултурне и плуријезичке образовне политике.

Ставови и закључци изнесени у овде анализираним мастер радовима (представљени на конференцијама, лиценцираним семинарима за обуку наставног кадра, неформалним округлим столовима релевантних стручних друштава, итд.) отворили су (у хармонији са активностима других актера, наравно) нови јавни простор за конструктивну дебату релевантних заинтересованих страна, укључујући и Министарство просвете, науке и технолошког развоја Републике Србије. Један од директних и видљивих резултата те дебате у последњих пар година јесте промена метода и техника евалуација постигнућа у страним језицима у формалном образовању Србије. Тестови који се данас користе на свим нивоима образовања (укључујући и универзитетско) припремају се у складу са релативним критеријумима дефинисаним у складу са Заједничким европским референтним оквиром за учење језика (Савет Европе, 2001), захваљујући, између осталог и активностима предводнички оријентисаним делатним заједницама наставника и наставница страних језика, који су успели да понуде одговарајућу аргументацију и одбране и наметну ставове којима штите интересе деце којој предају и задовоље потребе ширих заједница у којима живе.

\section{5. Предводништво као језичка образовна политика 21. века}

Језици представљају окосницу сваке друштвене интеракције и кључни аспект друштвеног живота уопште. Управо стога неопходно је да препознамо потребу да језици и њихова употреба у јавном, обра- 
зовном и административном (као и приватном) домену буду осетљиви на непрестану флуктуацију комуникативних потреба различитих говорних заједница. Неопходно је да разумемо и значај одлука у вези са језиком у формирању друштвених и културних значења и тумачења личних језичких избора (различитих језика, варијетета једног истог језика, стилова и регистара унутар једног варијетета, итд.). Стога је веома важно да језичку политику и планирање и језичку образовну политику сагледамо као динамичну интеракцију између различитих заинтересованих актера (говорне заједнице и њених комуникативних пракси, јавног мњења, образовног система, администрације и политике) и да схватимо да језичка политика не треба да се искључиво спушта “одозго-на-доле” са висина академских институција и политичких институција државе, већ да мора да укључи и знања, вештине и искуство и појединаца и делатних заједница које у вези са њом имају шта да кажу користећи при томе адекватну, научно засновану аргументацију. Када је у питању језичка образовна политика, јасно је да је неопходно активно учешће наставника и наставница “са терена", односно из наставне праксе, јер они представљају једну врсту медијатора између језичких менаџера и оних на које језичку политику треба да примењују. Управо због тога њих и сагледавамо као предводнике и предводнице који имају прилику и могућност да својим деловањем ублаже тензије, неспоразуме и спрече имплицитно или експлицитно одбацивање званичних језичких политика у конкретним образовним ситуацијама. Предводништво, свакако, подразумева и повећање степена личне и колективне одговорности, те наставни кадар усмерава и ка задовољењу потребе континуираног усавршавања и по завршетку формалног образовања. Стручна друштва и организације које се баве целоживотним учењем морају се у том смислу ангажовати и обезбедити оптималне услове за ширење критичке свести и знања неопходних за остваривање предводничке улоге у професионалним сферама деловања у области наставе језика. 


\section{Референце:}

Браун \& Левинсон (1987): Brown, P. \& S. Levinson. Politeness: Some universals in language usage. Cambridge: Cambridge University Press.

Витли (2004): Wheatley, M J. (3 ${ }^{\text {rd }}$ edition). Leadership and the New Science. Discovering Order in a Chaotic World. San Francisco, CA: Berrett-Koehler Publishers Inc.

Голдстин (1999): Goldstein, J. Emergence as a Construct. History and Issues. Emergence, 11: 110-125.

Гофман (1967): Goffman, E. Interaction ritual; essays on face-to-face behavior. Garden City, N.Y: Doubleday.

Дардер (1995): Darder, A. Buscando America: The Contributions of Critical Latino Educators to the Academic Development and Empowerment of Latino Students in the U.S. in Multicultural Education, Critical Pedagogy and the Politics of Difference edited by Christine E. Sleeter and Peter L. McLaren, New York: Suny Press.

Жуњић (2009): Жуњић, С. Моgерносӣ и филозофија. Београд: Плато books.

Илен (2001): Eelen, G. A Critique of Politeness Theories. Manchester: St. Jerome Publishing.

Кели и др. (2004): Kelly, M., M. Greenfell, R. Allan, C. Kriza and W. McEvoy. European Profile for Lanugage Teacher Education - A Frame of Reference. A Report to the European Commission Directorate General for Education and Culture. Online document $<$ http://ec.europa.eu/languages/documents/doc477_en.pdf, retrieved on October 5, 2011

Лејв (1988): Lave, J. Cognition in practice: Mind, mathematics and culture of everyday life. Cambridge UK: Cambridge University Press.

Рисенто (2000): Ricento, T. Historical and theoretical perspectives in language policy and planning. Journal of Sociolinguistics, 4: 196-213.

Рисенто (2006): Ricento, T. (ed.), An Introduction to Language Policy: Theory and Method. Malden, MA: Blackwell Publishing.

Сполски (2009): Spolsky, B. Language management. Cambridge: Cambridge UP.

Старк (2001): Stark, D. Ambiguous assets for uncertain environments: heterarchy in postsocialist firms, in: Paul Dimaggio (ed.), The Twenty- 
First Century Firm: changing economic organization in international perspective. Princeton, NJ: Princeton UP., pp. 69-104.

Толефсон (2002): Tollefson, J. W. (ed.), Language Policies in Education: Critical Issues. Mahwah, NJ: Lawerence Erlbaum.

Томасон \& Кауфман (1988): Thomason, S.G., Kaufman, T.. Language contact, creolization, and genetic linguistics. Berkeley: University of California Press.

Традгил (1983): Trudgill, P. Sociolinguistics. An Introduction to Language and Society. Penguin Books.

Филиповић \& Јовановић (2016): Filipović, J. \& A. Jovanović. Academic maturation and metacognitive strategies in academic research. Universal Journal of Educational Research, 4 (7):

Филиповић (1999): Filipović, J. Varijacije unutar padeških sistema u različitim tipovima srpskih varijeteta: u prilog jedinstvenoj teoriji jezičkih promena. Zbornik za filologiju i lingvistiku Matice srpske, XLII/1: 59-68.

Филиповић (2016): Filipović, J. Lingvistika i teorija kompleksnosti. jezičko liderstvo kao intergralni deo jezičke politike i planiranja u 21. veku. U: S. Gudurić \& M. Stefanović (ur.), Jezici i kulture u vremenu $i$ prostoru $V$. Novi Sad: Filozofski fakultet Univerziteta u Novom Sadu, str. 623-636.

Филиповић (2017): Filipović, J. Jezik, standardizacija, standdardnojezicka kultura i jezicka politika i planiranje, Glasnik odjeljenja drustvenih nauka, knjiga 23, CANU, str. 217-231.

Филиповић (2015): Filipović, J. Transdisciplinary approach to language study. The Complexity theory perspective. London: Palgrave Macmillan.

Фрејжер (1990): Fraser, B.. Perspectives on politeness. Journal of Pragmatics, 14: 219-236.

Хераертс (2003): Geeraerts, D. Cultural models of linguistic standardization. In R. Dirven, R. Frank \& M. Pütz (eds.), Cognitive Models in Language and Thought. Ideology, Metaphors and Meanings Berlin: Mouton de Gruyter, pp. 25-68.

Хокинс \& Нортон (2009): Hawkins, M. \& B. Norton. Critical language teacher education. In A. Burns \& J. Richards (eds.), Cambridge guide to second language teacher education. Cambridge: Cambridge University Press, pp. 30-39. 
Шнајдер \& Инграм (1993): Schneider, A. and H Ingram. Social Construction of Target Populations: Implications for Politics and Policy. The American Political Science Review, Vol. 87 (2): 334-347.

Jelena Filipović

\title{
LANGUAGE POLICY AND PLANNING AND LANGUAGE LEADERSHIP: EDUCATION FOR THE $21^{\text {ST }}$ CENTURY
}

\begin{abstract}
Summary
Herein, a critical review of language policy and planning and language education policy is outlined based on the analysis of the key principles of their functioning, namely language management and language leadership. A case study which investigates experiences of a group of students who learned about language policy and planning from the perspective of critical pedagogy and critical language analysis during their M.A. studies at the Faculty of Philology of the University of Belgrade is used to support the idea that language policy in the $21^{\text {st }}$ century cannot be applied within the top-down framework only, but that it also needs to take into consideration the ever-changing categories of individual and collective communicative and affective needs of relevant speech communities.
\end{abstract}

Keywords: language policy and planning, language education policy, language management, language leadership, Serbian educational system. 